\title{
"The internet and e-commerce diffusion in European countries (modeling at the example of Austria, Poland and Ukraine)"
}

\begin{tabular}{|c|c|}
\hline AUTHORS & $\begin{array}{l}\text { Tetiana Zatonatska (D https://orcid.org/0000-0001-9197-0560 } \\
\text { Oleksandr Dluhopolskyi (D https://orcid.org/0000-0002-2040-8762 } \\
\text { Iryna Chyrak (D) http://orcid.org/0000-0003-1593-7042 } \\
\text { Nataliya Kotys (D http://orcid.org/0000-0003-3499-0746 }\end{array}$ \\
\hline ARTICLE INFO & $\begin{array}{l}\text { Tetiana Zatonatska, Oleksandr Dluhopolskyi, Iryna Chyrak and Nataliya Kotys } \\
\text { (2019). The internet and e-commerce diffusion in European countries (modeling } \\
\text { at the example of Austria, Poland and Ukraine). Innovative Marketing , 15(1), 66- } \\
\text { 75. doi:10.21511/im.15(1).2019.06 }\end{array}$ \\
\hline DOI & http://dx.doi.org/10.21511/im.15(1).2019.06 \\
\hline RELEASED ON & Wednesday, 20 March 2019 \\
\hline RECEIVED ON & Thursday, 14 February 2019 \\
\hline ACCEPTED ON & Monday, 18 March 2019 \\
\hline LICENSE & $\begin{array}{l}(c) \text { EY } \\
\text { This work is licensed under a Creative Commons Attribution } 4.0 \text { International } \\
\text { License }\end{array}$ \\
\hline JOURNAL & "Innovative Marketing " \\
\hline ISSN PRINT & $1814-2427$ \\
\hline ISSN ONLINE & $1816-6326$ \\
\hline PUBLISHER & LLC "Consulting Publishing Company "Business Perspectives" \\
\hline FOUNDER & LLC "Consulting Publishing Company "Business Perspectives" \\
\hline
\end{tabular}

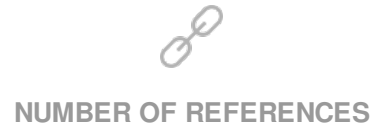

39
NUMBER OF FIGURES

4
ニニ:-

NUMBER OF TABLES

4

(C) The author(s) 2022. This publication is an open access article. 


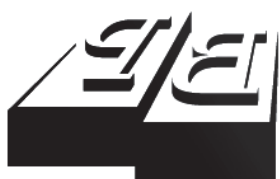

BUSINESS PERSPECTIVES

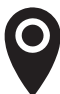

LLC "CPC "Business Perspectives" Hryhorii Skovoroda lane, 10, Sumy, 40022, Ukraine

www.businessperspectives.org

Received on: $14^{\text {th }}$ of February, 2019 Accepted on: $18^{\text {th }}$ of March, 2019

(C) Tetiana Zatonatska, Oleksandr Dluhopolskyi, Iryna Chyrak, Nataliya Kotys, 2019

Tetiana Zatonatska, Doctor of Economics, Professor, Taras Shevchenko National University of Kyiv, Ukraine.

Oleksandr Dluhopolskyi, Doctor of Economics, Professor, Ternopil National Economic University, Ukraine.

Iryna Chyrak, Ph.D. in Economics, Associate Professor, Ternopil National Economic University, Ukraine.

Nataliya Kotys, Ph.D. in Economics, Associate Professor, Ternopil National Economic University, Ukraine.

\section{(ㄷ) (i)}

This is an Open Access article, distributed under the terms of the Creative Commons Attribution 4.0 International license, which permits unrestricted re-use, distribution, and reproduction in any medium, provided the original work is properly cited.
Tetiana Zatonatska (Ukraine), Oleksandr Dluhopolskyi (Ukraine), Iryna Chyrak (Ukraine), Nataliya Kotys (Ukraine)

\section{THE INTERNET AND E-COMMERCE DIFFUSION IN EUROPEAN COUNTRIES (MODELING AT THE EXAMPLE OF AUSTRIA, POLAND AND UKRAINE)}

\begin{abstract}
This article analyzes the influence of Internet and e-commerce diffusion in the development of European countries. Conclusions about the faster spread of Internet technologies in the modern world, especially in developing countries, due to the achievement of so-called "saturation points" by developed countries of the world (e-commerce markets in Ukraine and Poland are at the stage of formation and active growth) have been made. The purpose of this article is to construct an economic and mathematical toolkit for investigating the impact of the Internet and e-commerce on indicators of economic development of the country. The methods of scientific analysis, description and synthesis, modeling and statistical analysis are used in the research. Models of technologies diffusion have been considered, and as a basis, the distribution of the Internet in Poland, Austria and Ukraine is forecasted.
\end{abstract}

Findings suggest that Internet technology spread has a significant impact on the development of e-commerce, and Internet development in different countries of the world. This study uses the classification of countries according to the World Bank Country Classification, which, since 2005, has ranked countries by GDP per capita into four groups:

1) low-income;

2) lower-middle-income;

3) upper-middle-income;

4) high-income.

It has been found that the pace of Internet technology and broadband Internet access spread is a lot higher in low-income countries due to the later beginning of the diffusion process, while in the high-income countries, the peak of Internet development has passed and the technology spread has slowed down.

\section{Keywords information and communication technologies, e-commerce, diffusion, Internet, GDP}

\section{JEL Classification $\quad$ C50, F02, F20, L86, O30}

\section{INTRODUCTION}

Due to the development of modern globalized society, the Internet has become a vital stimulus for progress not only in the world economy, but also in other spheres of human activity. Nowadays, it's difficult to find an area where this technology is not being used. In industry, for example, the Internet is used not only for the analysis of raw materials stocks, components, finished products, but also for marketing research, forecasting the demand for different types of products, finding new prospective partners, etc. Accounting transactions of firms are also based on Internet usage. The effectiveness of the public administration sector's activity largely depends on the level of interaction between households, firms and other sectors of the economy. It is clear 
that Internet usage within public administration provides access to organizational, legal, social, psychological and personnel information, as well as other factors simultaneously. As a result, both the work and organization of the public administration process become significantly more navigable.

Information and communication technologies are extremely important for the progress of Industry 4.0, which combines solutions, processes and technologies, which describe the high level of IT usage and the intensive degree of interconnection systems in individual business units. Nowadays, the United States, Japan, China and Germany have been recognized as the largest markets in the information and telecommunications sector (digital age transformation).

The purpose of the article is to predict the Internet diffusion in several European countries - Austria, Poland and Ukraine, which are similar in their territorial characteristics. The authors try to answer the question about the biggest potential for Internet diffusion among three countries of Europe accepted for comparison.

\section{LITERATURE REVIEW}

The research of technology distribution modeling has been developing since the late 1960s. In most cases, they were based on the use of logistic equations varieties that differed in the inclusion of additional factors that characterized the peculiarities of the spread of specific technologies.

The modern scientific literature devoted to the Internet diffusion emphasizes its exceptional role as a multiplier of socio-economic development (Roller \& Waverman, 2001; Kenny, 2003; Terzi, 2011; Zhen-Wei \& Pitt, 2003; Zhao et al., 2007; Niebel, 2018). In the work of Gort and Klepper (1982), the diffusion has been considered to "spread among a significant number of manufacturers involved in the manufacturing of a new product". The number of the Internet users is one of the indicators of inclusion to the consumption of a new product. Rogers emphasizes that "diffusion is a process in which innovation spreads over certain channels over time to members of the social system" (Rogers, 2003). Nowadays, this definition is generally accepted and it identifies four main elements: innovation, communication channels, time, and social system.

In the work of Pohjola (2003), the analysis of investments into information and communication technologies of 49 countries for the period 19932000 was carried out. In the paper of Chinn and Fairlie (2007), based on data from 161 countries for the period 1999-2001, the distribution and usage of personal computers and the Internet was analyzed. The authors determine the difference in consumers' revenues as a key reason for the rapid expansion of the Internet in developed countries, as compared to slower progress in developing countries. The work of Andres et al. (2007) analyzed the distribution of Internet technologies with an example of 214 countries for the period 19902004. Scientists also established a significant differentiation of Internet distribution in high- and low-income countries.

Internet diffusion models have been researched in many works devoted to developing countries. For example, in the work of Chong and Micco (2003), researchers evaluated Internet distribution in Latin America and concluded that Latin American countries had the advantage of lower service cost and could easily catch up with technology leaders, despite its late distribution. In another work (Beilock \& Dimitrova, 2003), it was proven that income per person is one of the most important factors determining the speed of Internet technology distribution.

However, in our opinion, it is not necessary to link the Internet distribution only with economic welfare. An important factor is also economic freedom, especially in low-income countries. The integral elements of the development of high technologies in the modern world are property rights protection, development of competition, liberal tax legislation, developed labor markets, democracy, etc. (Matthews, 2018). While on the contrary, economic secrecy and authoritarianism are inherent in low-income countries (Dlugopolskyi \& Zhukovska, 2010; Bergh et al., 2016). 
Table 1. Indicators of Internet cost, GDP per person and Index of Economic Freedom (IEF) in the context of some African countries, 2017

\begin{tabular}{|c|c|c|c|}
\hline Countries & Costs of broadband Internet, \$ per month & GDP per capita PPP, \$ & IEF \\
\hline Tunisia & $\begin{array}{ll}19.6 & \\
\end{array}$ & 11,987 & 58.9 \\
\hline Morocco & 39.3 & 8,612 & 61.9 \\
\hline Algeria & 32.1 & 15,150 & 44.7 \\
\hline Egypt & 12.3 & 12,994 & 53.4 \\
\hline Mauritania & 63.7 & 4,474 & 54.0 \\
\hline Gambia & 65.8 & 1,686 & 52.3 \\
\hline Sierra Leone & 113.4 & 1,791 & 51.8 \\
\hline Mali & 157.1 & 2,169 & 57.6 \\
\hline Niger & 115.2 & 1,153 & 49.5 \\
\hline Nigeria & 80.1 & 5,927 & 58.5 \\
\hline Burkina Faso & 933.9 & 1,884 & 60.0 \\
\hline Sudan & 95.8 & 4,580 & 49.4 \\
\hline Ethiopia & 65.9 & 2,113 & 52.8 \\
\hline Djibouti & 97.4 & 3,567 & 45.1 \\
\hline Kenya & 86.2 & 3,496 & 54.7 \\
\hline Tanzania & 115.2 & 3,283 & 59.9 \\
\hline Mozambique & 69.5 & 1,266 & 46.3 \\
\hline Zimbabwe & 170 & 2,277 & 44.0 \\
\hline South Africa & 59.3 & 13,403 & 63.0 \\
\hline Botswana & 79.7 & 18,146 & 69.9 \\
\hline Namibia & 464.3 & 11,528 & 58.5 \\
\hline Angola & 139.3 & 6,813 & 48.6 \\
\hline Gabon & 105.4 & 19,266 & 58.0 \\
\hline Cameroon & 63.3 & 3,359 & 52.0 \\
\hline Seychelles & 96.6 & 28,712 & 61.6 \\
\hline
\end{tabular}

For example, in certain African countries, where it was possible to obtain data of Internet traffic cost (see Table 1), we may analyze the link between the cost of the Internet and GDP per person, as well as the cost of the Internet and the Index of Economic Freedom.
As shown in Figure 1, there is an inverse and quite insignificant link the between the cost of the Internet and economic welfare in African countries. Figure 2 indicates a direct but also insignificant link between the cost of Internet and the Index of Economic Freedom.

Source: Built by the authors.

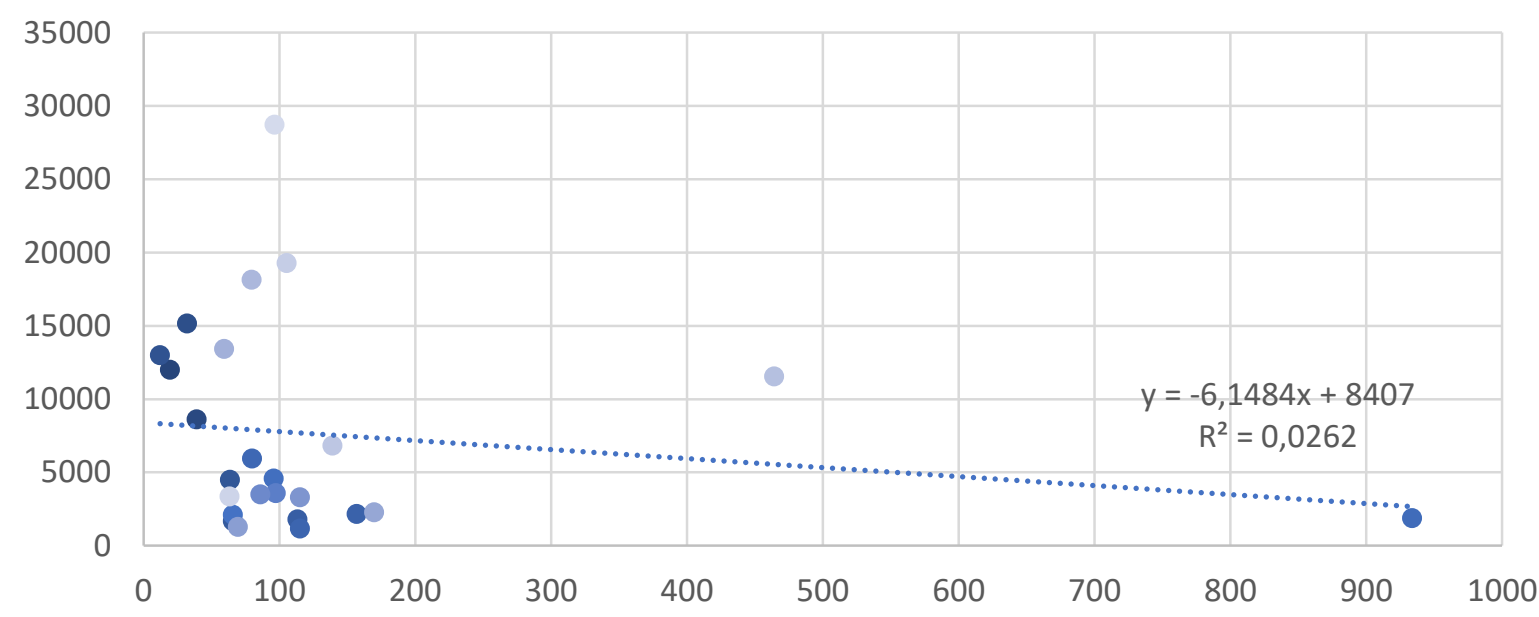

Figure 1. Interconnection of the Internet cost and GDP in Africa 
Source: Built by the authors.

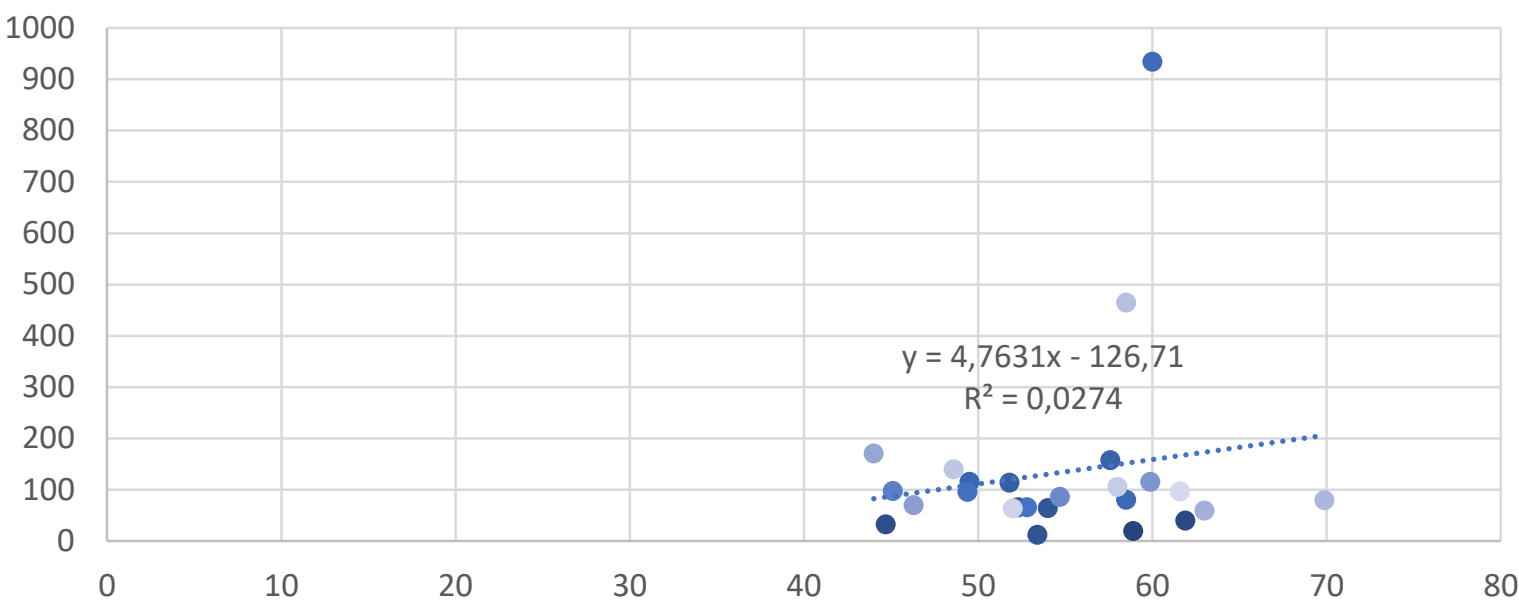

Figure 2. Correlation of the Internet cost and IEF in African countries

In general, a lot of works are devoted to the analysis of the impact of information technology related to productivity of the US and Canadian economies (Jorgenson \& Stiroh, 1995; Khan \& Santos, 2002; Oliner et al., 1994; Karlsson \& Liljevern, 2017), as well as Northern and Western European countries (Cette et al., 2002; Jalava \& Pohjola, 2002; Oulton, 2002). The issue of the spread of IT in Eastern European countries has not been completely solved (Zatonatska et al., 2018; Zatonatska, 2018), and therefore eliminates certain gaps in research of the impacts of the Internet technologies and e-commerce diffusion on the macroeconomic indicators of Ukraine's development.

\section{RESEARCH METHODOLOGY}

The article uses data of International Telecommunication Union (2018), which distinguishes both real and potential Internet users. This change in population is associated with potential consumers, since the number of Internet users is most often used in terms of population. This article uses the classification of countries according to the World Bank Country Classification, which, since 2005, has ranked countries by GDP per capita into four groups:
1) low-income;
2) lower-middle-income;
3) upper-middle-income;
4) high-income.

The calculations used data from the official websites of the World Bank and Eurostat for the period 1990-2017 (Eurostat, 2018; World Bank, 2018) for the distribution of the Internet and broadband Internet access. All calculations and modeling were made in Microsoft Excel and R Studio.

\section{RESULTS}

The number of Internet users is increasing every year. In 2017, the number of the worldwide network users increased by $6 \%$ and amounted to 4 billion people, or $53 \%$ of the Earth's population (according to the data of the UN, in 2017, the world's population was more than 7.6 billion people). However, Internet diffusion is still quite heterogeneous in terms of countries and continents. So, if in 1997 the number of Internet users in the USA was $22 \%$, and in 2004 it had already increased to $63 \%$, then in China in the same period the increase was only from $0.03 \%$ to $7.2 \%$, in Tanzania - from $0.0 \%$ to $0.9 \%$ (Andres et al., 2010). However, in 2016 , the number of Internet users in the United States amounted to $88.5 \%$, in China - 52.2\%, in Tanzania - 5.3\% (Internet Users by Country, 2016).

The Internet is the main base for the emergence and rapid development of e-commerce in the world and Ukraine. That is why the e-commerce growth rate largely depends on the speed of Internet distribution. As with any other technology, the process of Internet distribution can be described as a diffusion phenomenon, and its features and pat- 
terns may be reflected through a technology diffusion model.

In general, the model often used to describe the diffusion of technologies has the following form (Dubinina, 2015):

$$
\frac{d N(t)}{d t}=g(t, N(t))[N *-N(t)],
$$

where $N(t)$ is the accumulated sum of all those who accepted the technology by the time $t, N^{*}$ is the total number of potential consumers of technology, $g(t, N(t))$ is the probability of adopting the technology.

Different models are distinguished by assumptions that the authors define concerning to the function $g(t, N(t))$. In general, it is assumed that it is a linear function:

$$
g(t, N(t))=p+q N(t) .
$$

It is usually considered that the external factors which influence the speed of technological adoption are determined by the individuals' need in innovations and levels of marketing and advertising links, and the term $p\left(N^{*}-N(t)\right)$ corresponds to this. Internal factors are caused by the links and contacts between the active users of the technology and its potential customers, as a result of which information about the technology is transmitted, and the term $q \cdot N(t) \cdot\left[N^{*}-N(t)\right]$ corresponds to this process.

In the technology distribution model proposed in the work of Bass (1969), it was assumed that an individual's decision to use technology at time $t$ depended on the number of previous customers taking into account the innovation and imitation effect:

$$
\frac{d N}{d t}=\left(p+\frac{q}{N^{*}} N(t)\right) \cdot\left(N^{*}-N(t)\right),
$$

where $N^{*}$ is a market potential, $N(t)$ - the total number of those who accepted the technology at time $t, p$ - the coefficient of innovation, $q-$ the coefficient of imitation, $n(t)=d N / d t$ - the number of those who accepted the technology at time $t$.
For such a model, total sales on technology at time $t$ are determined by the formula:

$$
N(t)=N * \cdot \frac{1-e^{-(p+q) t}}{1-\frac{q}{p} \cdot e^{-(p+q) t}} .
$$

In the Bass's model, the time of the sales peak is defined as:

$$
T^{*}=\frac{1}{p+q} \cdot \ln \left(\frac{q}{p}\right) .
$$

The total sales at the peak of sales are calculated as follows:

$$
N\left(T^{*}\right)=N^{*}\left(0.5-\frac{p}{2 q}\right) .
$$

Most of the works devoted to the Internet distribution use the $\mathrm{S}$-curve to describe the diffusion of technologies. It is necessary to investigate data from the very beginning of technology in order to get the most accurate description of the distribution process.

In the work (Dubinina, 2015), this model was used to assess the Internet distribution in countries, divided into three groups by the population's income level.

The data about the Internet and broadband Internet access distribution in several countries was used from the World Bank's official website for the period 1990-2015 (World Bank, 2015). The basis of these calculations was a discrepancy version of the Bass model in the assumption that for one year $d N(t) / d t \cong N(t)-N(t-1)$, which is presented in the formula:

$$
\begin{aligned}
& n(t+1)=p N^{*}+ \\
& +(q-p) N(t)-\frac{q}{N^{*}} N(t)^{2}
\end{aligned}
$$

where $N^{*}$ is the total number of potential users of the technology; $N(t)$ is the cumulative sum of all users of technology at time $t ; p$ - the coefficient of innovation; $q$ - the coefficient of imitation; $n(t)$ the growth of the number of the technology users in the period $[t-1, t]$. 
Table 2. The estimation of the parameters of the Internet distribution model and broadband Internet access by groups of countries (per 100 population)

Source: Dubinina (2015).

\begin{tabular}{|c|c|c|c|c|c|c|c|c|c|}
\hline & \multirow{2}{*}{ Groups of countries } & \multicolumn{4}{|c|}{ Diffusion of Internet } & \multicolumn{4}{|c|}{$\begin{array}{c}\text { Diffusion of broadband Internet } \\
\text { access }\end{array}$} \\
\hline & & $\mathbf{N}^{*}$ & $\mathbf{q}$ & $\mathbf{p}$ & $\begin{array}{l}\text { Standard } \\
\text { deviation }\end{array}$ & $\mathbf{N}^{*}$ & $\mathbf{q}$ & $\mathbf{p}$ & $\begin{array}{l}\text { Standard } \\
\text { deviation }\end{array}$ \\
\hline Group 1 & Countries with high income level & 79.0 & 0.26 & 0.017 & 1.97 & 27.2 & 0.38 & 0.032 & 1.00 \\
\hline Group 2 & Countries with medium income level & 42.4 & 0.34 & 0.003 & 1.38 & 7.1 & 0.44 & 0.017 & 0.30 \\
\hline Group 3 & Countries with low income level & 10.8 & 0.40 & 0.001 & 0.4 & 0.2 & 0.85 & 0.014 & 0.02 \\
\hline
\end{tabular}

The estimation of the model's parameters for the considered period is given in Table 2 .

As it was confirmed in the work of Dubinina (2015), in the low-income countries, the process of Internet diffusion began later. If in the first group of countries Internet users averaged 0.23 per 100 people of the population in 1990, then for the second group the distribution process began in 1993, and for the third one - only in 1997. While the countries of the first group have passed the peak of development of this technology, and the process of its spread has slowed down approaching the socalled "saturation point", then the third group was characterized by the continuation of growth. The imitation coefficient value $(q)$ is the highest of the groups considered, and the innovation coefficient $(p)$ is the lowest one here. The forecast for the Internet distribution for these groups of countries with preservation of existing trends is represented in Figure 3.

Similarly, the technology of broadband Internet access in the above-mentioned groups of countries is developing (see Table 2). One of the differences in the distribution of this technology is the lack of a large time delay at the beginning of its distribution in countries of second and third groups, when comparing to the first group. In general, as well as for Internet diffusion, group 3 received the lowest innovation $p$ and the highest imitation coefficients $q$.

However, according to Dubinina (2015), the degree of Internet distribution within a particular group to a large extent depends on the economic development of each individual country. Thus, among countries in group 2, the lowest value of

Source: Dubinina (2015).

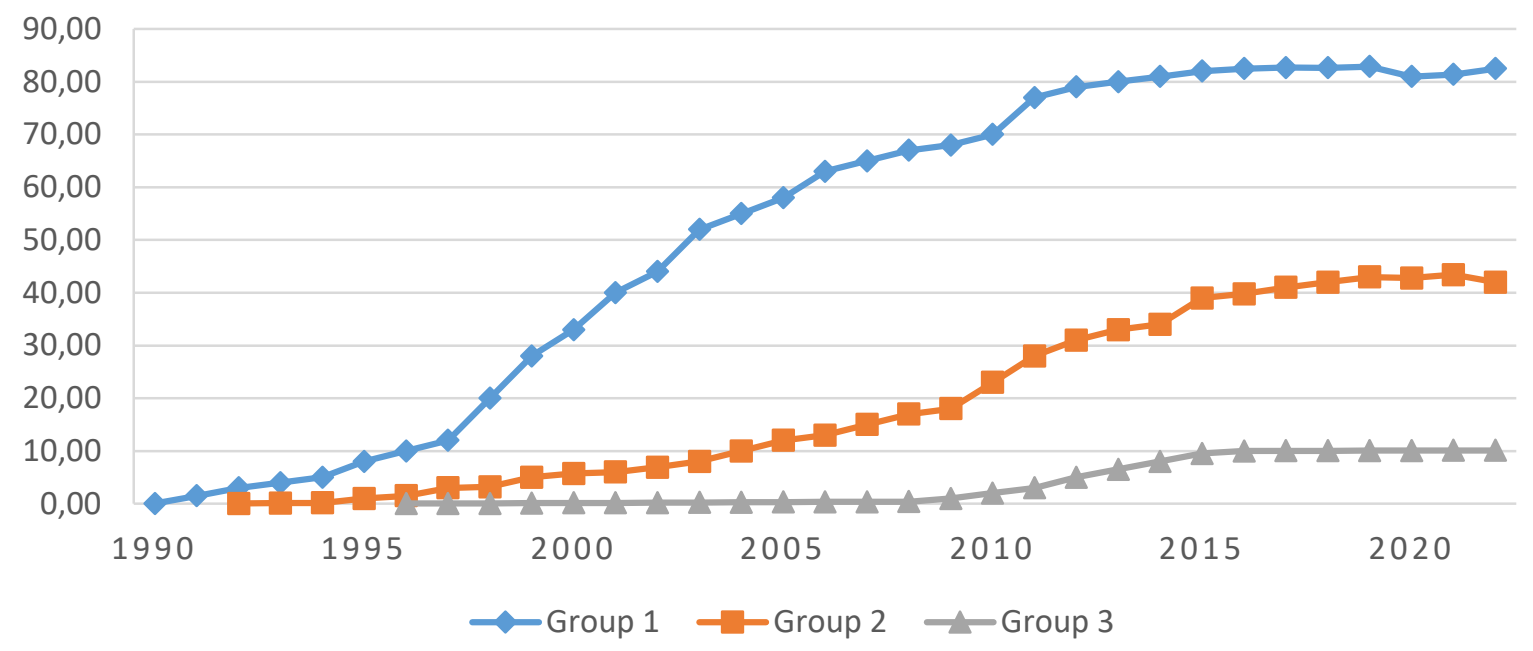

Figure 3. The forecast of Internet diffusion for different groups of countries for the period up to 2022 
Table 3. The indicators of Internet distribution and broadband Internet access in some countries (per 100 people)

Source: Dubinina (2015)

\begin{tabular}{|c|c|c|c|c|c|c|c|c|}
\hline \multirow[b]{2}{*}{ Country } & \multicolumn{4}{|c|}{ Diffusion of Internet } & \multicolumn{4}{|c|}{ Diffusion of broadband Internet access } \\
\hline & $\mathbf{N}^{*}$ & $\mathbf{q}$ & $\mathbf{p}$ & $\begin{array}{l}\text { Standard } \\
\text { deviation }\end{array}$ & $\mathbf{N}^{*}$ & $\mathbf{q}$ & $\mathbf{p}$ & $\begin{array}{l}\text { Standard } \\
\text { deviation }\end{array}$ \\
\hline India & 35.22 & 0.34 & 0.000 & 0.87 & 1.30 & 0.69 & 0.008 & 0.08 \\
\hline Brazil & 80.56 & 0.42 & 0.023 & 3.59 & 10.95 & 0.40 & 0.015 & 0.47 \\
\hline Columbia & 61.78 & 0.37 & 0.003 & 2.31 & 10.35 & 0.44 & 0.018 & 0.48 \\
\hline China & 49.99 & 0.46 & 0.001 & 2.14 & 18.30 & 0.35 & 0.015 & 0.61 \\
\hline Turkey & 48.67 & 0.37 & 0.009 & 2.08 & 10.19 & 0.76 & 0.039 & 0.73 \\
\hline Romania & 47.36 & 0.40 & 0.009 & 1.93 & 15.37 & 0.72 & 0.033 & 1.09 \\
\hline Mexico & 78.13 & 0.18 & 0.007 & 1.59 & 10.90 & 0.73 & 0.010 & 0.70 \\
\hline
\end{tabular}

the parameter $N^{*}$, which estimates the total number of potential technology users (market potential), is obtained for India, which, according to the World Bank, is in the group of countries with an income below the average (see Table 3).

Among the countries with average development, the lowest indicator of market potential for Internet and broadband Internet access distribution has been obtained for India, while the highest market potential and the highest innovation rate are for China. Undeniably, the speed of Internet distribution and the number of Internet users directly affects the development of e-business and the consumers' ability to buy products and services online. Therefore, it is relevant to determine the pace of development of this technology in Ukraine comparing to other European countries (the results of Poland and Austria). Such a choice of countries is caused by their territorial similarities - all three countries are situated in Europe, where there is mostly plain terrain and they are located in close proximity to one another, and also have similar indicators of population per meter square of the country's territory (in 2017, the density of the population in Ukraine was 74 persons/ $\mathrm{m}^{2}$, in Poland -123 persons $/ \mathrm{m}^{2}$, in Austria - 98 persons $/ \mathrm{m}^{2}$ ) (Wikipedia, 2018).

The basis for the calculations was the difference version of the Bass model, which is given in formula 7. The study used the annual data on the number of Internet users in Ukraine, Poland and Austria in thousands of people, the growth rate of
Internet users for each year was calculated. Using the model 7, we can obtain the model of Internet technology diffusion for each country, the evaluation of which is given in Table 4.

Table 4. The estimation of parameters of the Internet distribution model in the researched countries (data per 100 people)

Source: Completed by the authors as a results of modeling on the basis of Eurostat (2018), World Bank (2018), State Statistics Service of Ukraine (2018).

\begin{tabular}{|c|c|c|c|c|}
\hline \multirow[b]{2}{*}{ Country } & \multicolumn{4}{|c|}{ Diffusion of Internet } \\
\hline & $\mathbf{N}^{*}$ & $\mathbf{q}$ & $\mathbf{p}$ & $\begin{array}{l}\text { Standard } \\
\text { deviation }\end{array}$ \\
\hline Ukraine & 65.0 & 0.14 & 0.004 & 1.89 \\
\hline Poland & 74.5 & 0.03 & 0.007 & 1.87 \\
\hline Austria & 87.0 & 0.04 & 0.054 & 1.22 \\
\hline
\end{tabular}

Thus, analyzing the results of the modeling, it should be mentioned that the process of active Internet development in Ukraine began later in comparison to Poland and Austria - only in 1996 (in Poland and Austria - in 1992). The coefficient of imitation in Ukraine is the highest (0.14), and the innovation coefficient is the lowest (0.004), which indicates continuation of the active increase in the number of Internet users in the country and distribution of this technology. Austria as a country with a higher level of technological development at this stage also has the highest rates of Internet distribution and e-commerce development. That is why the rate of potential Internet users here is the largest one ( 87 per 100 people). 


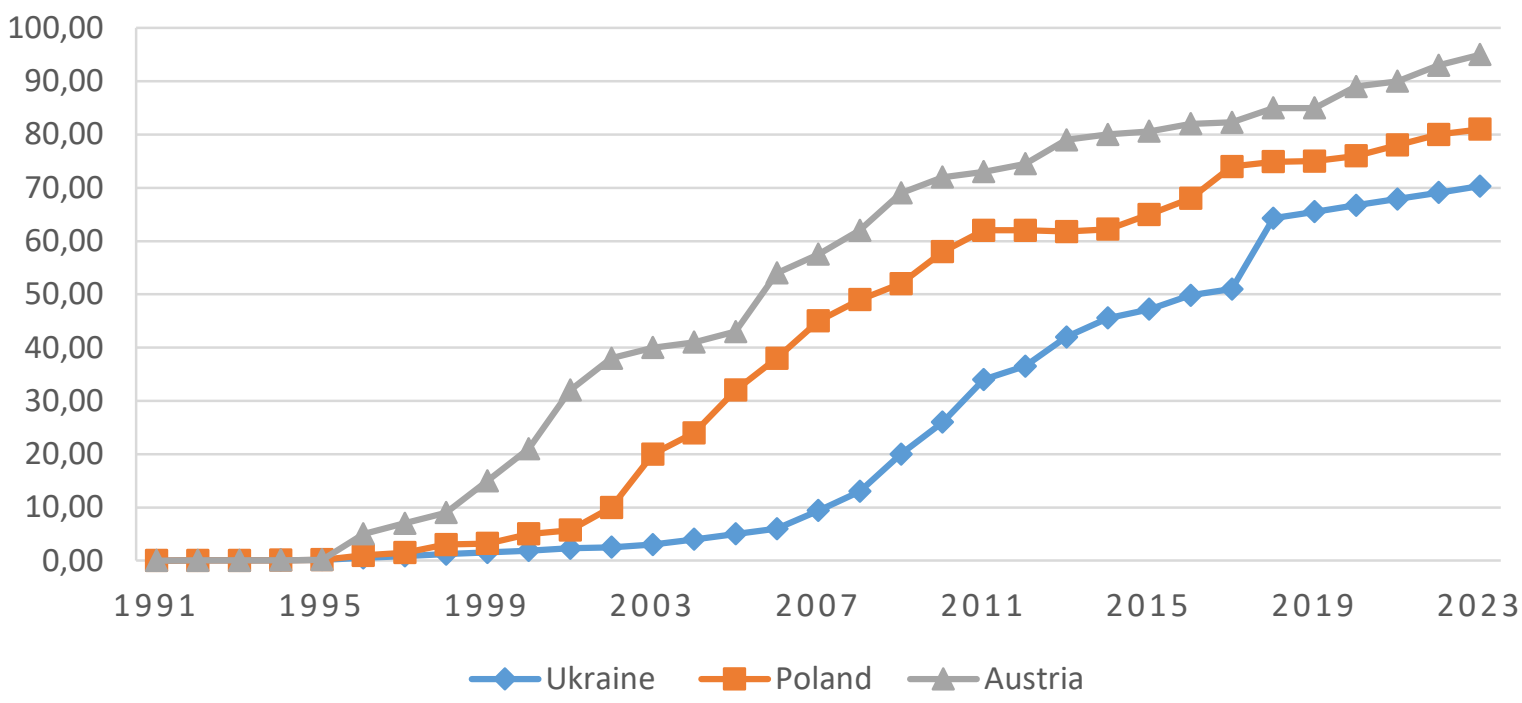

Figure 4. The forecast of Internet diffusion for Ukraine, Poland and Austria for the period up to 2025

Additionally, it should be noted that the growth rates of the development of Internet technology in Poland and Austria are slowing down every year, as their technology markets are closer to the point of full saturation when comparing to Ukraine. If the trends that currently exist in these countries are saved, then it is possible to can get a forecast for the spread of Internet technology by 2025 (see Figure 4).

Thus, it can be argued that Austria has the highest potential for Internet diffusion among the coun- tries accepted for comparison - it is a country with a high level of technological development and the highest rate of the Internet penetration (85\% of the total population of the country in 2017). Poland takes the second position among the three countries and also has significant potential for the development in this direction. Ukraine, which does not have technological development indicators yet, in comparison to its two European neighbors, however, it is still ahead of them for the growth rate of Internet users, and thus has all chances to catch up with Austria and Poland in the near future.

\section{CONCLUSION}

The pace of Internet technology spread has a significant impact on the development of e-commerce, and Internet development, in turn, depends on the level of development of the country. It has been found that the pace of Internet technology and broadband Internet access spread is a lot higher in low-developed countries due to the later beginning of the diffusion process, while in the high-income countries the peak of Internet development has passed and the technology spread has slowed down, approaching the "point of saturation".

Taking into account the results of modeling, we consider that the spread of Internet technologies undoubtedly contributes towards the development of e-commerce in Austria, Poland and Ukraine. Ukraine has significant potential for accelerating the spread of Internet and e-business. The processes of decentralization associated with the creation of united territorial communities in Ukraine only accelerate the spread of broadband Internet access, since each united community must be provided with a connection that requires joint efforts of telecommunication operators and authorities of different levels of government. 


\section{REFERENCES}

1. Andres, L., Cuberes, D., Diouf, M., \& Serebrisky, T. (2007). The Diffusion of the Internet: a Cross-country Analysis. Telecommunications Policy, 34, 323-340.

2. Bass, F. M. (1969). A New Product Growth for Model Consumer Durables. Management Science, 15(5), 215-227.

3. Beilock, R., \& Dimitrova, D. V. (2003). An Exploratory Model of Inter-country Internet Diffusion. Telecommunications Policy, 27, 237-252.

4. Bergh, A., Erlingsson, G. O., Ohrvall, R., \& Sjolin, M. (2016). A Clean House? Studies of Corruption in Sweden (160 p.). Nordic Academic Press.

5. Cette, G., Kokoglu, Y., \& Mairesse, J. (2002). The Diffusion of Information and Communication Technologies in France. Measurement and Contribution to Growth and Productivity. International Productivity Monitor, 4, 27-38. Retrieved from https://econpapers.repec.org/article/slsipmsls/ v_3a4_3ay_3a2002_3a3.htm

6. Chinn, M. D., \& Fairlie, R. W. (2007). The Determinants of the Global Digital Divide: a Crosscountry Analysis of Computer and Internet Penetration. Oxford Economic Papers, 59(1), 16-44. https:// doi.org/10.1093/oep/gpl024

7. Chong, A., \& Micco, A. (2003). The Internet and the Ability to Innovate in Latin America. Emerging Markets Review, 4(1), 53-72. Retrieved from https:// ideas.repec.org/a/eee/ememar/ v4y2003ilp53-72.html

8. Dilley, J. (2018). How Much Should I Be Paying for High-Speed Internet? Retrieved from https:// www.highspeedinternet.com/ resources/how-much-should-i-bepaying-for-high-speed-internetresource

9. Dlugopolskyi, O. V., \& Zhukovska, A. Y. (2010). Corruption and Social Reforms: Aspects of Coinfluence. Actual Problems of Economics, 8, 229-240.
10. Dubinina, M. H. (2015). Моделирование динамики взаимосвязи макроэкономических показателей и показателей распространения ИТ в развитых и развивающихся странах [Modelirovaniye dinamiki vzaimosvyazi makroekonomicheskikh pokazateley i pokazateley rasprostraneniya IT $\mathrm{v}$ razvitykh i razvivayushchikhsya stranakh]. Works of ISA RAS, 65(1), 24-37. Retrieved from http://www.isa.ru/proceedings/images/documents/201565-1/t-15-1_24-37.pdf

11. EspresoTV (2018). У 2018-му люди проведуть в мережі мільярд років [U 2018-ти liudy provedut $v$ merezhi miliard rokiv]. Retrieved from https://espreso. tv/news/2018/01/30/v_2018_lyudy_provedut_v_merezhi_milyard_rokiv_statystyka

12. Eurostat (2018). Available at http:// ec.europa.eu/eurostat

13. Gort, M., \& Klepper, S. (1982). Time paths in the diffusion of product innovations. The Economic Journal, 92, 630-653.

14. Index of Economic Freedom (2019). Promoting Economic Opportunity, Individual Empowerment \& Prosperity. Retrieved from https://www.heritage.org/index

15. International Telecommunication Union (2018). World Telecommunication Indicators. ICT Indicators Database. Retrieved from https:// crtc.gc.ca/eng/library/detail/cata$\log 7833$

16. Internet live stats (2016). Internet Users by Country. Retrieved from http://www.internetlivestats.com/ internet-users-by-country

17. Jalava, J., \& Pohjola, M. (2002). Economic Growth in the New Economy: Evidence from Advanced Economies. Information Economics and Policy, 14(2), 189210.

18. Jorgenson, D., \& Stiroh, K. (1995). Computers and Growth. Economics of Innovation and New Technology, 3, 109-115.
19. Karlsson, E., \& Liljevern, J. (2017). ICT Investment and the Effect on Economic Growth (Bachelor Thesis). International business school “Jönköping University". Retrieved from http://www.diva-portal.org/ smash/get/diva2:1110483/FULLTEXT01.pdf

20. Kenny, C. (2003). The Internet and Economic Growth in LessDeveloped Countries: a Case of Managing Expectations? Oxford Development Studies, 31, 99-113.

21. Khan, H., \& Santos, M. (2002). Contribution of ICT use to Output and Labor Productivity Growth in Canada (Bank of Canada Working Paper 2002-7). Retrieved from https://www.bankofcanada.ca/ wp-content/uploads/2010/02/ wp02-7.pdf

22. Matthews, D. (2014). The Ecology of Democracy: Finding Ways to Have a Stronger Hand in Shaping Our Future (231 p.). Ohio: Kettering Foundation Press. Retrieved from https://www.kettering org/wp-content/uploads/EcologyIntroduction.pdf

23. McCarthy, N. (2017). The Most and Least Expensive Countries for Broadband. Retrieved from https://www.forbes.com/sites/ niallmccarthy/2017/11/22/ the-most-and-least-expensivecountries-for-broadband-infographic/\#5760485823ef

24. Niebel, T. (2018). ICT and Economic Growth: Comparing Developing, Emerging and Developed countries. World Development, 104, 197-211. Retrieved from https://doi.org/10.1016/j. worlddev.2017.11.024

25. Oliner, S .D., Sichel, D. E., Triplett, J. E., \& Gordon, R. J. (1994). Computers and Output Growth Revisited: how big is the Puzzle? Brookings Papers on Economic Activity, 2, 273-334.

26. Oulton, N. (2002). ICT and Productivity Growth in the UK. Oxford Review of Economic Policy, 18, 363-379.

27. Pohjola, M. (2003). The Adoption and Diffusion of ICT across Countries: Patterns and Determinants. 
In D. C. Jones (Ed.), The neweconomy hand-book (pp. 77-100). San Diego, CA: Elsevier-Academic Press.

28. Rogers, E. M. (2003). Diffusion of Innovation (5th ed.). New York: The Free Press, Simon \& Schuster Inc.

29. Roller, H., \& Waverman, L. (2001). Telecommunications Infrastructure and Economic Development: a Simultaneous Approach. American Economic Review, 91, 909-923.

30. State Statistics Service of Ukraine (2018). Available at http://www. ukrstat.gov.ua

31. Statistics Times (2018). List of African countries by GDP per capita. Retrieved from http://statisticstimes.com/economy/africancountries-by-gdp-per-capita.php
32. Terzi, N. (2011). The Impact of E-Commerce on International Trade and Employment. ProcediaSocial and Behavioral Sciences, 24, 745-753.

33. Transformation of the Digital Age (n.d.). Retrieved from https:// www.tatsachen-ueber-deutschland. de/uk

34. Wikipedia (2018). List of countries by population density. Retrieved from https://simple.wikipedia.org/ wiki/List_of_countries_by_population_density

35. World Bank. (2018). Retrieved from http://www.worldbank.org

36. Zatonatska, T. (2018). Models for Analysis of Impact of the E-Commerce on Indicators of Economic Development of Ukraine, Poland and Austria. Marketing and Man- agement of Innovations, 2, 44-53. Retrieved from http://mmi.fem. sumdu.edu.ua/en/node/1071

37. Zatonatska, T., Rozhko, O., \& Tkachenko, N. (2018). Modern Trends of Impact on Economic Development of Countries: ECommerce and R\&D. Marketing and Management of Innovations, 4 , 129-135. http://doi.org/10.21272/ mmi.2018.4-12

38. Zhao, H., Kim, S., Suh, T., \& Du, J. (2007). Social Institutional Explanations of Global Internet Diffusion: a Cross-country Analysis. Journal of Global Information Management, 15(2), 2-55.

39. Zhen-Wei, Q. C., \& Pitt, A. (2003). Contribution of Information and Communication Technologies to Growth. Washington, DC: World Bank. 